\title{
Influence of PTFE on water transport in gas diffusion layer of polymer electrolyte membrane fuel cell
}

\author{
Yanan Chen ${ }^{1}$, Tian Tian ${ }^{1}$, Zhaohui Wan ${ }^{1,2}$, Fan Wu ${ }^{1}$, Jinting Tan ${ }^{1, *}$, Mu Pan ${ }^{1, *}$ \\ ${ }^{1}$ Hubei Key Laboratory of Fuel Cells, State Key Laboratory of Advanced Technology for Materials \\ Synthesis and Processing, 430070, Wuhan China; \\ ${ }^{2}$ Wuhan WUT New Energy Co., Ltd, 430223, Wuhan China \\ *E-mail: tanjinting@whut.edu.cn, panmu@whut.edu.cn
}

doi: $10.20964 / 2018.04 .53$

Received: 21 December 2017 / Accepted: 10 February 2018 / Published: 6 March 2018

Hydrophobic coatings (PTFE) have been introduced in gas diffusion layers to improve the performance of fuel cells. Eight different cell configurations with various PTFE loading in cathode and anode GDLs were assembled. The oxygen transport ability and the water behavior are investigated based on the limiting current theory. The results demonstrate that fuel cell with a PTFE loading in GDL of 10 wt. $\%$ has the best performance of $1.003 \mathrm{~W} \cdot \mathrm{cm}^{-2}$ under $1686.6 \mathrm{~mA} \cdot \mathrm{cm}^{-2}$. The high operating temperature $\left(\geq 60^{\circ} \mathrm{C}\right)$ will be properly applied to characterize the oxygen transport through limiting current method. Moreover, the content of PTFE in GDL used in anode will affect the water behaviors of cathode CLs which will determine the $\mathrm{R}_{\mathrm{NP}}$ in corresponding cathode, especially low $\mathrm{Pt}$ loading.

Keywords: PEMFC, PTFE, GDL, limiting current, oxygen transport, water behavior

\section{FULL TEXT}

(C) 2018 The Authors. Published by ESG (www.electrochemsci.org). This article is an open access article distributed under the terms and conditions of the Creative Commons Attribution license (http://creativecommons.org/licenses/by/4.0/). 